\title{
CTSG Gene
}

National Cancer Institute

\section{Source}

National Cancer Institute. CTSG Gene. NCI Thesaurus. Code C104053.

This gene plays a role in protein degradation. 